\title{
Application of protein-phenolic based coating on tomatoes (Lycopersicum esculentum)
}

\author{
Aplicação de coberturas proteicas e fenólicas em tomates (Lycopersicum esculentum)
}

\author{
Eliane Pereira CIPOLATTI ${ }^{1 *}$, Larine KUPSKI ${ }^{1}$, Meritaine da ROCHA ${ }^{1}$, Melissa dos Santos OLIVEIRA ${ }^{2}$, \\ Jaqueline Garda BUFFON ${ }^{1}$, Eliana Badiale FURLONG ${ }^{1}$
}

\begin{abstract}
The aim of this study was to investigate the use of protein-phenolic based coating made from fermented rice bran on cherry tomatoes (Lycopersicum esculentum). Tests were performed with glycerol 3\% (v/v), glycerol with protein-phenolic rice bran extract (5\%), glycerol with protein-phenolic extract after 96 hours of fermentation (5\%), and a control (without coating). The coated cherry tomatoes were kept at room temperature for 28 days. Mass loss, $\mathrm{pH}$ and acidity, total soluble solids, and carotenoids were determined every 96 hours. The coating made from the biomass extract reduced the carotenoid and acidity levels in the fruits studied by 17 and $21.1 \%$, respectively, compared to the control. The coating proved an efficient barrier to water vapor with mass loss of $57 \%$ less than the control suggesting that it can be used as an alternative for vegetable tissue conservation.
\end{abstract}

Keywords: rice bran; fermentation process; conservation.

\section{Resumo}

Este trabalho teve como objetivo estudar a utilização de películas, à base de compostos proteicos e fenólicos provenientes de farelo de arroz fermentado, em tomates (Lycopersicum esculentum). Foram realizados testes com: glicerol 3\% (v/v); glicerol com extrato fenólico e proteico do farelo de arroz (5\%); glicerol com extrato fenólico e proteico da biomassa gerada em 96 hours (5\%), e um controle (sem a película). Os tomates revestidos foram mantidos à temperatura ambiente durante 28 dias, sendo determinados, a cada 96 horas, os seguintes aspectos: a perda de massa, o pH e a acidez, os sólidos solúveis totais e os carotenoides. A película elaborada com os extratos da biomassa reduziu os níveis de carotenoides e acidez dos frutos estudados em 17 e 21,1\%, respectivamente, em relação ao controle. A película também foi eficiente como barreira ao vapor de água; assim, com perda de massa $57 \%$ inferior à do controle, sugere-se que esta poderá ser utilizada como alternativa para conservação desse tecido vegetal.

Palavras-chave: farelo de arroz; processo fermentativo; conservação.

\section{Introduction}

Tomato is climacteric fruit, and therefore it is a highly interesting system to study maturation and ripening processes because of the postharvest metabolic changes. Storage life is a function of several factors including transpiration, postharvest diseases, and quick ripening and senescence causing production loss (BOGGIO et al., 2000; CHEN et al., 2001).

Coating can act as barriers to moisture and oxygen during processing, handling, and storage (XU et al., 2007). The use of coating for protection purposes represents an economical advantage avoiding the need for climate controlled storage, which incurs operational costs and requires special equipment (FALCAO-RODRIGUES; MOLDAO-MARTINS; BEIRAODA-COSTA, 2007). Biopolymers such as carbohydrates, lipids, and proteins can be used as coating with the purpose to modify the internal atmosphere of fruit and vegetables (CISNEROSZEVALLOS; KROCHTA, 2003). Polysaccharides have been successfully used in coating formulation offering barrier against gases. However, due to their hydrophilic nature, they are not offer good barrier against humidity. Lipids offer excellent barrier against moisture, but they present problems related to oxidative stability. Protein-based coatings are known for being biodegradable and offering good barrier against gas. They also offer a mechanical protection, which increases the shelf life and minimizes food deterioration (CHO; PARK; RHEE, 2002). Proteins are made up of long carbonated chains, with 20 different monomers, which allows the necessary molecular interaction for coating generation (DANGARAN; TOMASULA; QI, 2009).

It was demonstrated that rice bran fermentation with the microorganism Rhizopus oryzae provides a significant increase in the protein content in the biomass, resulting in a continuous and cohesive matrix (OU et al., 2005; SILVEIRA; BADIALE-FURLONG, 2007) and in the antioxidant activity of

\footnotetext{
Received 27/8/2010

Accepted 21/5/2012 (005012)

Escola de Química e Alimentos, Universidade Federal do Rio Grande - FURG, Rua Eng. Alfredo Huch, 475, Centro, CP 474, CEP 96201-900, Rio Grande, RS, Brasil, e-mail:elianecipolatti@yahoo.com.br

${ }^{2}$ Eixo Tecnológico de Produção Alimentícia, Instituto Federal Farroupilha de Educação, Ciência e Tecnologia, Santo Augusto, RS, Brasil

${ }^{*}$ Corresponding author
} 
the phenolic compounds in the bran (OLIVEIRA et al., 2010). These properties may help protect against oxidative damage.

To our knowledge, there is no published study on the use of phenolic and protein compounds obtained during solid state fermentation as coating for the preservation and extension of storage life of fresh fruit. The aim of this study was to investigate the use of protein-phenolic based coating made from fermented rice bran using glycerol as plastificant in order to extend the shelf life of tomatoes.

\section{Materials and methods}

\subsection{Raw material}

The rice bran used in this study was provided by IRGA (Instituto Rio-Grandense de Arroz); it was packed in $3 \mathrm{~kg}$ polypropylene bags and kept under refrigeration until use. The cherry tomatoes (Lycopersicum esculentum) were cultivated in the city of Feliz (Rio Grande do Sul State - RS).

\subsection{Fermentation of the rice bran}

Solid state fermentation (SSF) was carried out in tray bioreactors $\left(29 \times 17 \times 5.5 \mathrm{~cm}^{3}\right)$. Rice bran substrate $(100 \mathrm{~g})$, with particle diameter of $0.5 \mathrm{~mm}$ (mesh $32 \mathrm{~mm}$ ), was autoclaved in tray bioreactors forming a thin layer $(2 \mathrm{~cm})$. Next, it was homogenized with $45 \mathrm{~mL}$ of the nutrient solution $\left(\mathrm{KH}_{2} \mathrm{PO}_{4}\right.$ 2 g.L.-, $\mathrm{MgSO}_{4} 1$ g.L.- $\mathrm{L}^{-1} \mathrm{NH}_{2} \mathrm{CONH}_{2} 1.8$ g.L.- in $\left.\mathrm{HCl} 0.4 \mathrm{~N}\right)$. The initial spore concentration of Rhizopus oryzae CCT 7560 was $4.0 \times 10^{6}$ spores. $\mathrm{g}^{-1}$ (BADIALE-FURLONG; CACCIAMANI; GARDA-BUFFON, 2007). Moisture was adjusted to $50 \%$ by the addition of sterile water, and the trays were covered with sterilized gauze to allow aeration. The incubation was carried out in a fermentation chamber (TECNAL TE - 403, Piracicaba, Brazil) at $30^{\circ} \mathrm{C}$, and one tray bioreactor was removed from the incubator every 24 hours for five days resulting in the biomasses of $0,24,48,72,96$, and 120 hours, which were stored at $-18^{\circ} \mathrm{C}$ for later use (OLIVEIRA et al., 2010).

\section{Protein extract}

The method used to obtain the protein extract was adapted from Adebiyi et al. (2008), which consisted of defatting fermented and unfermented rice bran with petroleum ether. Next, protein extraction was performed in alkaline environment (pH 9.5) using $10 \mathrm{~g}$ of defatted bran and $70 \mathrm{~mL}$ of $\mathrm{NaOH} 0.02 \mathrm{M}$ adjusting the $\mathrm{pH}$ with $\mathrm{NaOH} 6 \mathrm{M}$. The mixture was stirred for 30 minutes at $160 \mathrm{rpm}$ (MARCONI MA - 410, Piracicaba, Brazil), centrifuged (CIENTEC 5000R, Piracicaba, Brazil), and precipitated with acetone in a ratio of 1:3 (v/v). Protein was quantified by the method of Lowry et al. (1951).

\section{Phenolic extract}

The phenolic compounds were cold extracted with methanol 1:5 (w:v) using the method described by Souza et al. (2009). The antioxidant activity of these compounds was determined by the DPPH free radical sequestration method (SOUSA et al., 2007).

\subsection{Formulation and application of the coating on cherry tomato (Lycopersicum esculentum)}

The tomatoes were selected according to size and color (ruddy) (BRASIL, 1995), washed in water, and immersed in a sodium hypochlorite solution $100 \mathrm{mg} . \mathrm{L}^{-1}$ for 5 minutes. The coating solutions were prepared dissolving glycerol and protein-phenolic extract from fermented and unfermented rice bran in distilled water. Three different treatments were evaluated: glycerol ( $3 \% \mathrm{v} / \mathrm{v})$ (treatment 1$)$; coating solution containing glycerol (3\% v/v) and protein-phenolic (5\%) rice bran extracts (treatment 2); coating solution containing glycerol $(3 \% \mathrm{v} / \mathrm{v})$ and protein-phenolic extracts $(5 \%)$ from the biomass (treatment 3); and an uncoated control. The coating was applied by fruit immersion in the different treatments for 1 minute with further drainage of excess. Next, they were placed on trays and kept at room temperature $\left(20-25^{\circ} \mathrm{C}\right)$ for 28 days. The useful life of tomatoes coated with the different treatments was monitored every 96 hours.

\subsection{Life cycle follow-up}

The mass loss was determined by gravimetry, and it was expressed in g.100 g $\mathrm{g}^{-1}(\%)$ of the initial mass of the fruit (ALI et al., 2010).

A digital $\mathrm{pH}$ meter was used for measuring the $\mathrm{pH}$. The acidity was determined by neutralization with $\mathrm{NaOH} 0.1 \mathrm{~N}$, and the results were expressed in citric acid percentage (ASSOCIATION..., 2000).

Soluble solids were determined $\left({ }^{\circ} \mathrm{Brix}\right)$ in an Abbé refractometer according to (ASSOCIATION..., 2000) with diluted sample 1:5 (w:v). The totals carotenoids were determined according to Carvalho et al. (2011) by extraction using acetone in the ratio of $1: 8(\mathrm{w}: \mathrm{v})$ and stirring at $200 \mathrm{rpm}$ in a shaker for 1 hour. Next, the extract was filtered in vacuum conditions by means of a Kitassato flask wrapped with aluminum foil to avoid photo-oxidation of pigments. The samples were washed three times with acetone for complete extraction of pigments. The content was transferred to a recipient containing $45 \mathrm{~mL}$ of petroleum ether. Next, distilled water was added to remove any remaining acetone solution. The pigment solution in petroleum ether was transferred to a volumetric flask and then diluted to $100 \mathrm{~mL}$ for further reading at the wavelength of $470 \mathrm{~nm}$. The carotenoids content was expressed by Equation 1 .

$\mu g \cdot g^{-1}=\frac{\left(A \cdot V \cdot 10^{6}\right)}{M \cdot 100 \cdot A^{1 \%}}$

where: A is the solution absorbance at a wavelength of $470 \mathrm{~nm}$; $\mathrm{V}$ is the final volume of the solution; $\mathrm{A}^{1 \%}$ is the absorbance of a particular pigment in a specific solvent, and $\mathrm{M}$ is the sample mass taken for analysis. The absorptivity coefficient of the carotenoids extracts in petroleum ether is 3450 .

\subsection{Statistical analysis}

All determinations were done in triplicate and the results were submitted to variance analysis (ANOVA) with significance level of 5\% ( $\mathrm{p}<0.05)$ and Tukey Studentized Range test. 


\section{Results and discussion}

\subsection{Selection of the extracts for coating application}

The fermentation process increases nutrient availability in raw materials due to the changes resulting from the metabolic activity of microrganismos (WAINWRIGHT, 1995). In the present study, rice bran was fermented by the microorganism Rhizopus oryzae CCT 7560 resulting in an increase in the protein level from 155 (non-fermented bran) to 276, 348, 286, 332, 375, and 359 g.kg for $^{-1}, 24,48,72,96$ and 120 hours, respectively. There was an increase of $35.9 \%$ in the protein after 96 hours in relation to 0 hour. An increase of $400 \%$ was also observed in the phenolic compounds after 96 hours. According to Oliveira et al. (2010), this time interval resulted in an increase in the amount of protein and phenolic compounds with antioxidant capacity who found an increase of $49 \%$ in the protein and an increase of $366 \%$ in the phenolic compounds after fermentation by the same microorganism. The protein obtained by fermentation demonstrated an improvement in the gelling properties allowing an improvement in coating elasticity (DANGARAN; TOMASULA; QI, 2009). The increase in the antioxidant properties as a function of phenolic liberation makes the extract interesting to prevent oxidative process and favor the cross linking between protein chains. This represents a decrease in the permeability, which would prevent mass loss.

\subsection{Life cycle follow-up}

Maintaining fruit mass indicates the integrity of the cell walls. It is related with the respiratory activity decrease, and it indicates the protective effect of coatings. Moisture is lost during transpiration when water is converted from liquid to gas. When produce is harvested, it loses its source of water, so recuperation from water loss is not possible. When water is lost, the turgor decreases and this water stress also causes metabolic alterations, changing enzyme activity, which may result in senescence acceleration (OLIVAS; BARBOSA-CÁNOVAS, 2009). Figure 1 shows tomatoes mass loss (a) and total soluble solids when they were coated with the three treatments during 28 days.

The mass loss in the control group was the highest, $53 \%$ after 28 days of experiment, which can be related to the absence of the protective coating. The coating containing glycerol and extracts from the fermented bran (treatment 3) was more efficient as a barrier to mass loss, $43 \%$ lower than the control group on the last day of experiment. Fruit weight loss during senescence has been observed by other authors (YAMAN; BAYOINDIRLI, 2002; ALI et al., 2010), which results in the metabolic degradation of the cell wall decreasing the water retention capacity observed during senescence. In this case, the mass loss was decreased suggesting delayed senescence.

The weight loss reduction was probably due to the effects of the coating as a semi-permeable barrier against $\mathrm{O}_{2}, \mathrm{CO}_{2}$, moisture, and solute movement, thus reducing respiration, water loss, and oxidation reaction rates (BALDWIN et al., 1999) and this may influence, mainly, consumer's preference. This behavior can be due to the efficiency of the protein barrier created by the coating, which prevented the dissection of the fruits that tend to have the walls degraded and the water released causing tissue wilting.

It can be observed in Figure 1 that all treatments showed total soluble solids (TSS) increase. The increase in the TSS content during the experiment is due to the pectin degradation with the carbohydrates release. The results suggest that there was a delay in the degradation reactions, retarding fruit ripening. The treatments that reduced pectin degradation were those containing protein and phenolic compounds and smaller mass loss. García et al. (2010), investigating a chitosan coating on papaya, verified a similar behavior to that found in this study, an increase in TSS content for the coating with chitosan $1 \%$ in lactic acid, Tween 80, and oleic acid.

The $\mathrm{pH}$ and acidity as citric acid of the samples submitted to the different treatments (Table 1) showed no significant

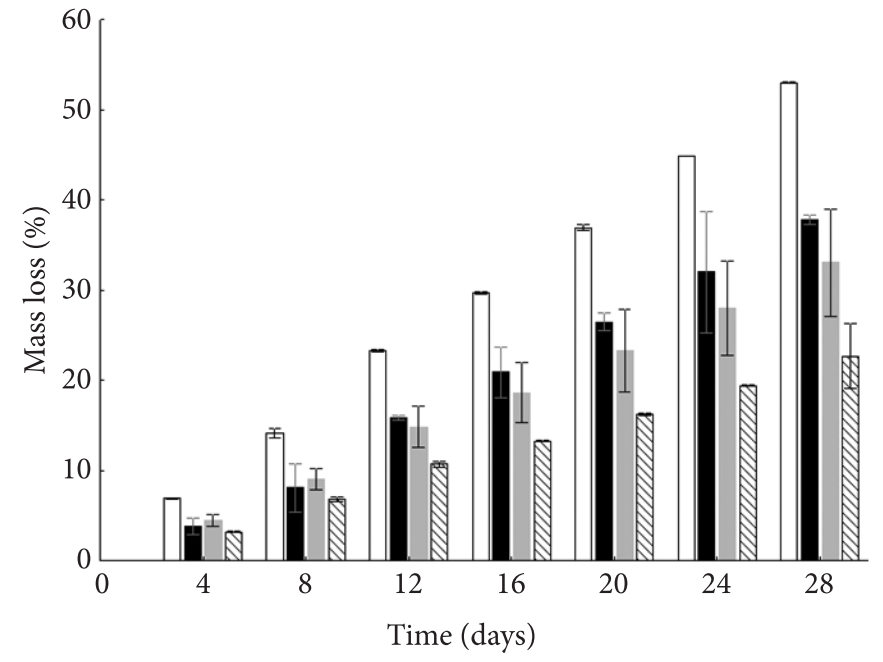

(a)

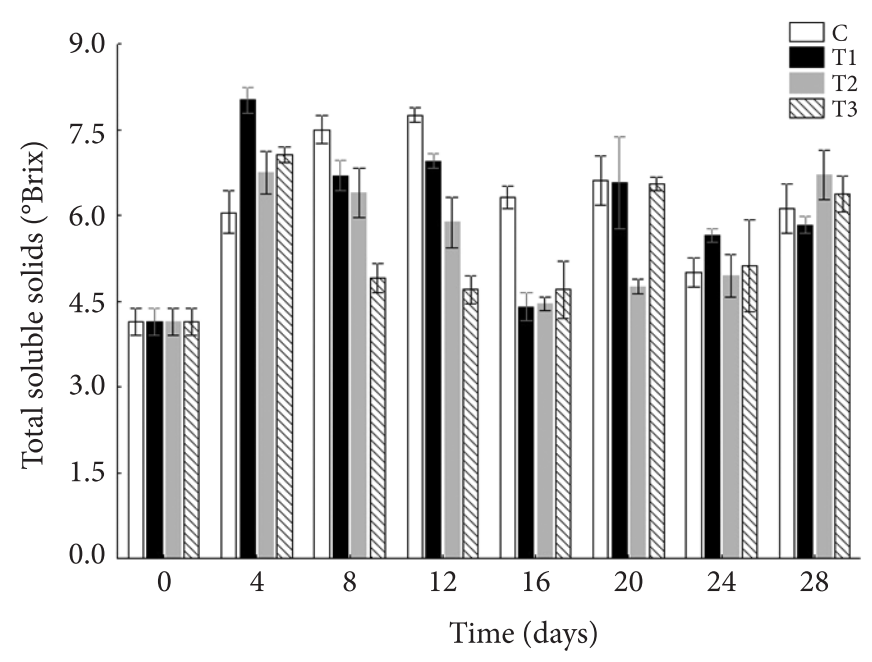

(b)

Figure 1. Effect of different coatings: C (uncoated); T1 (glycerol); T2 (glycerol and rice bran extracts); T3 (glycerol and biomass extracts) on tomatoes mass loss (a) and total soluble solids (b). 
Cipolatti et al.

Table 1. $\mathrm{pH}$ and acidity of tomatoes in the different treatments during storage.

\begin{tabular}{|c|c|c|c|c|}
\hline \multirow{2}{*}{ Days } & \multicolumn{4}{|c|}{$\mathrm{pH}$} \\
\hline & $\mathrm{C}$ & $\mathrm{T} 1$ & $\mathrm{~T} 2$ & T3 \\
\hline 0 & $4.42 \pm 0.01^{\mathrm{aD}}$ & $4.42 \pm 0.01^{\mathrm{aCD}}$ & $4.42 \pm 0.01^{\mathrm{aB}}$ & $4.42 \pm 0.01^{\mathrm{aE}}$ \\
\hline 4 & $4.46 \pm 0.02^{\mathrm{aC}}$ & $4.40 \pm 0.00^{\mathrm{dcD}}$ & $4.43 \pm 0.01^{\mathrm{caB}}$ & $4.48 \pm 0.01^{\mathrm{baD}}$ \\
\hline 12 & $4.50 \pm 0.03^{\mathrm{bB}}$ & $4.50 \pm 0.01^{\mathrm{bAB}}$ & $4.48 \pm 0.03^{\mathrm{cA}}$ & $4.60 \pm 0.01^{\mathrm{aA}}$ \\
\hline 16 & $4.41 \pm 0.01^{\mathrm{aD}}$ & $4.33 \pm 0.01^{\mathrm{aE}}$ & $4.36 \pm 0.02^{\mathrm{aC}}$ & $4.40 \pm 0.01^{\mathrm{aF}}$ \\
\hline 28 & $4.43 \pm 0.00^{\mathrm{aCD}}$ & $4.55 \pm 0.02^{\mathrm{aA}}$ & $4.42 \pm 0.02^{\mathrm{aB}}$ & $4.54 \pm 0.01^{\mathrm{aAB}}$ \\
\hline \multirow{2}{*}{ Days } & \multicolumn{4}{|c|}{ Acidity (\% citric acid) } \\
\hline & $\mathrm{C}$ & $\mathrm{T} 1$ & $\mathrm{~T} 2$ & T3 \\
\hline 0 & $0.80 \pm 0.00^{\mathrm{aE}}$ & $0.80 \pm 0.00^{\mathrm{aE}}$ & $0.80 \pm 0.00^{\mathrm{aC}}$ & $0.80 \pm 0.00^{\mathrm{aD}}$ \\
\hline 4 & $1.20 \pm 0.20^{\mathrm{aC}}$ & $1.25 \pm 0.21^{\mathrm{aA}}$ & $1.25 \pm 0.02^{\mathrm{aB}}$ & $1.18 \pm 0.05^{\mathrm{aBC}}$ \\
\hline 24 & $1.58 \pm 0.06^{\mathrm{aA}}$ & $1.08 \pm 0.02^{\mathrm{bD}}$ & $1.56 \pm 0.06^{\mathrm{aA}}$ & $1.64 \pm 0.10^{\mathrm{aA}}$ \\
\hline 28 & $1.66 \pm 0.06^{\mathrm{aA}}$ & $1.25 \pm 0.02^{\mathrm{bA}}$ & $1.53 \pm 0.11^{\mathrm{abA}}$ & $1.31 \pm 0.09^{\mathrm{bcB}}$ \\
\hline
\end{tabular}

Values are express as means $+\mathrm{SD}$. The values in each column with the same overwritten letter (lower case) are not significantly different (p $<0.05)$. The values in each line with the same overwritten letter (uppercase) are not significantly different $(\mathrm{p}<0.05)$. C: uncoated; T1: glycerol; T2: glycerol and rice bran extracts; T3: glycerol and biomass extracts.

difference $(\mathrm{p}<0.05)$. Davila-Avina et al. (2011), studying tomatoes coated with mineral oil, found that the initial $\mathrm{pH}$ of the fruit coated with mineral oil was 4.2, similar to that found in this study, 4.4. After the $24^{\text {th }}$ day, treatment 3 was lower comparing with the others showing that the application of coatings modified the internal atmosphere and the endogenous $\mathrm{CO}_{2}$ and $\mathrm{O}_{2}$ concentration of the fruit retarding ripening.

Acidity is directly related to the organic acids concentration in the fruits, and it depends on several intrinsic and extrinsic factors such as: cultivars, fertilization, soil management, irrigation, and some physiological factors (leaf area, organic biosynthesis, etc.) (CHIEN; SHEU; YANG, 2007). During the 28 days of storage, a tendency toward increasing acidity was observed.

The variations in the total carotenoids contents of the tomatoes during the 28 days of storage are shown in Figure 2. (GARCÍA et al., 2009). In this study, this aspect can be observed since, during the tomatoes storage, there was an increase in the carotenoids content. The increase was of $60.5 \%$ in the control and $33.2 \%$ in treatment 3 at end of the storage period indicating that the use of coating also provides a delay in the chlorophyll degradation.

Ilahy et al. (2011) compared the lycopene content present in tomatoes cultivar 'Rio Grande' at different maturation stages and found $1.6 \mu \mathrm{g} \cdot \mathrm{g}^{-1}$ in green, $8.2 \mu \mathrm{g} \cdot \mathrm{g}^{-1}$ in green-orange, $26.7 \mu \mathrm{g} . \mathrm{g}^{-1}$ in orange-red and $97.0 \mu \mathrm{g} . \mathrm{g}^{-1}$ in red-ripe tomatoes, which confirms the increase in the pigment with the maturation degree evolution.

The reactions during fruit maturation and senescence are independent; however, in order to improve shelf life, the rate of

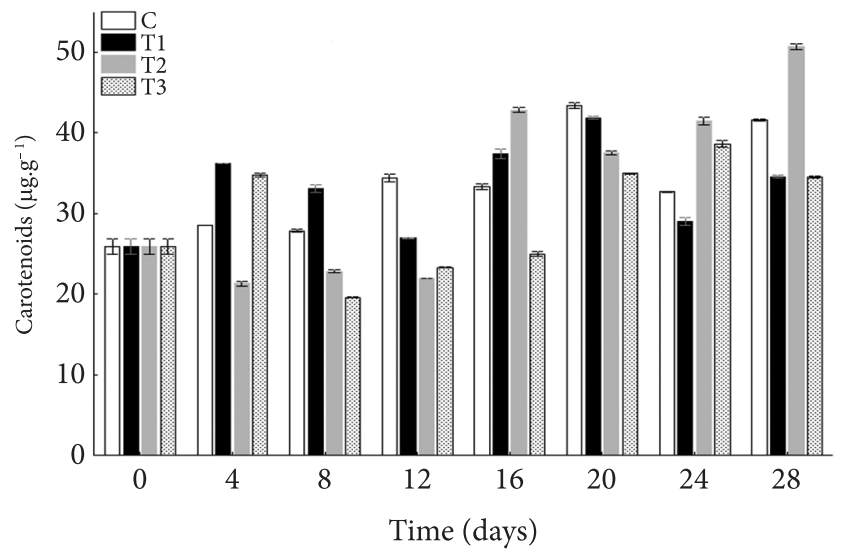

Figure 2. Effect of different coatings: C (uncoated); T1 (glycerol); T2 (glycerol and rice bran extracts); T3 (glycerol and biomass extracts) on tomatoes carotenoids content.

chemical reaction should be decreased The coating obtained in treatment 3 proved able to retard the tomatoes senescence by decreasing the main metabolic reactions.

\section{Conclusion}

The use of protein-phenolic based coating made from the biomass fermented by Rhizopus oryzae (CCT 7560) combined with glycerol on tomatoes (Lycopersicum esculentum) decreased maturation reactions indicated by the decrease in the mass loss rate, $\mathrm{pH}$, and acidity and increase in total carotenoids in relation to the control (without coating). Therefore, the use of coating provides an extended conservation period and also adds value to the product. 


\section{Acknowledgements}

The authors are grateful to the IRGA Institute (Instituto Rio Grandense do Arroz) for supplying rice bran.

\section{References}

ADEBIYI, A. P. et al. Rice bran protein-based edible coating. International Journal of Food Science and Technology, v. 43, n. 3, p. 476-483, 2008. http://dx.doi.org/10.1111/j.13652621.2006.01475.x

ALI, A. et al. Gumarabic as a novel edible coating for enhancing shelf-life and improving postharvest quality of tomato (Solanumlycopersicum L.) fruit. Postharvest Biology and Technology, v. 58, n. 42-47, 2010.

ASSOCIATION OF OFFICIAL ANALYTICAL CHEMISTS - AOAC. Official methods of analysis. 17th ed. Maryland: AOAC, 2000.

BADIALE-FURLONG, E.; CACCIAMANI, J. L. M.; GARDA-BUFFON, J. Fermentação fúngica: Enriquecimento protéico e degradação de micotoxinas em farelo de cereal contaminado com aflatoxina B1 e ocratoxina A. Brazilian Journal of Food Technology, v. 10, n. 4, p. 233-239, 2007.

BALDWIN, E. A. et al. Effect of two edible coatings with different permeability characteristics on mango (Mangiferaindica L.) ripening during storage. Postharvest Biology and Technology, v. 17, p. 215-226. 1999.

BOGGIO, S. B. et al. Changes in the amino acid composition and nitrogen metabolizing enzymes in ripening fruit of Lycopersicon esculentum Mill. Plant Science, v. 159, p. 125-133, 2000. http:// dx.doi.org/10.1016/S0168-9452(00)00342-3

BRASIL. Ministério da Agricultura Pecuária e Abastecimento - MAPA. Portaria no 553, de 30 de agosto de 1995. Dispõe sobre a Norma de Identidade, Qualidade, Acondicionamento e Embalagem do Tomate in natura, para fins de comercialização e Revoga as especificações de Identidade, Qualidade, Acondicionamento e Embalagem do Tomate, estabelecidas pela Portaria n 76, de 25 de fevereiro de 1975. Diário Oficial da República Federativa do Brasil, Brasília, DF, set. 1995.

CARVALHO, L. M. J. et al. Total carotenoid content, $\alpha$-carotene and $\beta$-carotene, of landrace pumpkins (Cucurbita moschata Duch): A preliminary study. Food Research International, 2011. http:// dx.doi.org/10.1016/j.foodres.2011.07.040

CHEN, G. P. et al. Inhibiting expression of a tomato ripening associated membrane protein increases organic acids and reduces sugar levels of fruit. Planta, v. 212, p. 799-807, 2001. PMid:11346954. http:// dx.doi.org/10.1007/s004250000431

CHIEN, P. J.; SHEU, F.; YANG, F. H. Effects of edible chitosan coating on quality and shelf life of sliced mango fruit. Journal Food Engineering, v. 78, p. 225-229, 2007. http://dx.doi.org/10.1016/j. jfoodeng.2005.09.022

CHO, S. Y.; PARK, J. W.; RHEE, C. Properties of laminated coatings from whey powder and sodium caseinate mixtures and zein layers. Lebensmittel-Wissenschaft und-Technologie - Food Science Technology, v. 35, p. 135-139, 2002.

CISNEROS-ZEVALLOS, L.; KROCHTA, J. M. Whey protein coatings for fresh fruits and relative humidity effects. Journal of Food Science, v. 68, p. 176-181, 2003. http://dx.doi.org/10.1111/j.1365-2621.2003. tb14136.x
DANGARAN, K.; TOMASULA, P. M.; QI, P. Structure and function of protein-based edible films and coating. In: EMBUSCADO, M. E, HUBER, K. C. Edible Films and Coatings for Food Applications. Ed. Springer, 2009. p. 25-57.

DAVILA-AVINA, J. E. J. et al. Effect of edible coatings, storage time and maturity stage on overall quality of tomato fruits. American Journal of Agricultural and Biological Science, v. 6, p. 162-171, 2011. http://dx.doi.org/10.3844/ajabssp.2011.162.171

FALCAO-RODRIGUES, M. M.; MOLDAO-MARTINS, M.; BEIRAO-DA-COSTA, M. L. DSC as a tool to assess physiological evolution of apples preserved by edible coatings. Food Chemistry, v. 102, p. 475-480, 2007. http://dx.doi.org/10.1016/j. foodchem.2006.05.016

GARCÍA, M. et al. Effects of chitosan coating on mass transfer during osmotic dehydrationof papaya. Food Research International, v. 43, p. 1656-1660, 2010. http://dx.doi.org/10.1016/j.foodres.2010.05.002

GARCÍA, M. A. et al. Structure and function of protein-based edible films and coating. In: EMBUSCADO, M. E.; HUBER, K. C. Edible Films and Coatings for Food Applications. Ed. Springer, 2009. p. 169-203.

ILAHY, R. et al. Antioxidant activity and bioactive compound changes during fruit ripening of high-lycopene tomato cultivars. Journal of Food Composition and Analysis, v. 24, p. 588-595, 2011. http:// dx.doi.org/10.1016/j.jfca.2010.11.003

LOWRY, O. H. et al. Protein measurement with the Folin Phenol Reagent. Journal Biological Chemistry, p. 265-275, 1951. PMid:14907713.

OLIVAS, G. I. I.; BARBOSA-CÁNOVAS, G. Edible films and coatings for fruits and vegetables. Chemistry and Material Science, p. 211-244, 2009. http://dx.doi.org/10.1007/978-0-387-92824-1_7

OLIVEIRA, M. S. et al. Physico-chemical characterization of fermented rice bran biomass. CyTA - Journal of Food, v. 8, n. 3, p. 229-236, 2010.

OU, S. et al. Role of ferulic acid in preparing edible films from soy protein isolat. Journal of Food Engineering, v. 70, p. 205-210, 2005. http://dx.doi.org/10.1016/j.jfoodeng.2004.09.025

SILVEIRA, C. M.; BADIALE-FURLONG, E. Characterization of nitrogenated compounds in solid state fermented bran. Ciência e Tecnologia de Alimentos, v. 27, n. 4, p. 805-811, 2007. http:// dx.doi.org/10.1590/S0101-20612007000400021

SOUSA, C. M. M. et al. Fenóis Totais e Atividade Antioxidante de Cinco Plantas Medicinais. Química Nova, v. 30, n. 2, p. 351-355, 2007. http://dx.doi.org/10.1590/S0100-40422007000200021

SOUZA, M. M. et al. Estudo das condições de extração de compostos fenólicos de cebola (Allium cepa L.). Revista Instituto Adolfo Lutz, v. 2 , n. 68 , p. 26-34, 2009.

WAINWRIGHT, M. Introducción a la Biotecnología de los Hongos. Zaragoza: Acribia, 1995. p. 228.

XU, W. T. et al. Postharvest grapefruit seed extract and chitosan treatments of table grapes to control Botrytis cinerea. Postharvest Biolology and Technology, v. 46, n. 1, p. 86-94, 2007. http://dx.doi. org/10.1016/j.postharvbio.2007.03.019

YAMAN, O.; BAYOINDIRLI, L. Effects of an edible coating and cold storage on shelf-life and quality of cherries. Lebensmittel-Wissenschaft und-Technologie - Food Science Technology, v. 35, p. 146-150, 2002. 